\title{
DETERMINANTS AND IMPLICATIONS OF THE TOURISM MULTIPLIER EFFECT IN EU ECONOMIES. TOWARDS A GORE-PERIPHERY PATTERNP
}

\author{
Gabriela Carmen Pascariu ${ }^{1 *}$ and Bogdan-Constantin Ibănescu ${ }^{2}$ \\ 1)2) "Alexandru Ioan Cuza" University of Iași, Romania
}

Please cite this article as:

Pascariu, G.C. and Ibănescu, B.C., 2018. Determinants and Implications of the Tourism Multiplier Effect in EU Economies. Towards a CorePeriphery Pattern? Amfiteatru Economic, 20(Special no. 12), pp. 982-997.

\section{DOI: $10.24818 / \mathrm{EA} / 2018 / \mathrm{S} 12 / 982$}

\section{Article History}

Received: 23 August 2018

Revised: 21 September 2018

Accepted: 12 October 2018

\begin{abstract}
Tourism is considered an opportunity for ensuring sustainable growth and reducing economic gaps for many less developed countries and regions. Being one of the most dynamics industries, tourism proves to be strongly resilient, with a high level of involvement and multiplication for receiver economies. The multiplication potential is, however, dependent upon a series of factors (endogenous and exogenous), insufficiently analysed in the literature, and the impact on growth and convergence is controversial. This paper aims to bring additional insights from this perspective, the main purpose of the research being to identify the macroeconomic determinants responsible for the higher values of the tourism multiplier effect and to highlight the potential of this industry to reduce the disparities between the economies of the European Union EU. Using the Stepwise regression and a series of indicators that associate the economic, social and spatial dimensions of European tourism, the main determinants of multiplier effects (on GDP and job creation) are identified and, then, the processes of multiplication from the perspective of centre-periphery dynamics are analysed. The research results indicated that tourism development in the Union reflects a centre-periphery model and has a high potential for contributing to reducing intra-EU disparities.
\end{abstract}

Keywords: tourism, European Union, tourism multiplier effect, stepwise regression, tourism competiveness, centre-periphery pattern.

JEL Classification: R11, Z32.

*Corresponding author, Gabriela Carmen Pascariu: gcpas@uaic.ro 


\section{Introduction}

Tourism is one of the fastest growing industries of the $\mathrm{XX}^{\text {th }}$ and $\mathrm{XXI}^{\text {st }}$ century and is becoming a central point in world economy. According to World Tourism Organisation (UNWTO), during 2017 were accounted 1,32 billion arrivals worldwide (UNWTO, 2018) with an average growth rate of $4.6 \%$, higher than other key sectors of the global economy, such as manufacturing (4.2\%), information and communication technologies (3.6\%), financial services $(2.5 \%)$ or constructions $(2.4 \%)$. In fact, for seven years in a row, tourism growth $(4 \%)$ exceeded the world economy growth $(2.5 \%)$, and in the long run tourism arrivals are expected to grow by $3.3 \%$ per year until 2030 .

The impact on the economy is considerable. Tourism has a direct contribution on World GDP of 3,1\% (WTTC, 2018), however the total contribution on World GDP reached $10,2 \%$, for a total of US\$ 7,6 trillion, sustaining around 118 million jobs directly $(3,8 \%)$ and approximatively 313 million jobs indirectly ( 1 in 10 worldwide). The difference is due to what is known in scientific literature as the tourism multiplier effect and it refers to the positive effects or additional income resulted from tourism or "how many times money spent by a tourist circulates through a country's economy" (Rusu, 2011). The multiplier effect of tourism activities is well known, although there is no broad agreement on evaluation methods. Instead far too little research was conducted on the macroeconomic and tourism competitiveness factors that can increase the multiplier effect. The aim of this study was to evaluate and validate the factors responsible for higher values of tourism multiplier effect and to search for the existence of a core-periphery pattern in tourism multiplier effect distribution.

We took into consideration that regional development and tourism are closely interconnected in European policies, considering: a. the dynamics of the tourism industry globally and regionally; b. the importance of tourism for the European economy and the potential contribution of this industry in achieving the strategic goals of the Union (for example, related to economic growth and the creation of jobs); c. the interdependencies between the tourism industry and sustainable development of the European Union as an institutionalised development model through the Treaty of Lisbon, with a potentially high contribution to reducing gaps in economic, social and territorial development (Mazilu, 2012; Pascariu și Duarte, 2017).

According to World Trade \& Tourism Organisation, in the European Union, the direct contribution of tourism to GDP is generally over 3\% (3.6\% in 2016) but reaches to approximately $10 \%(10.2 \%$ in 2016$)$, when also including the indirect and induced effects. For the next 10 years, it is anticipated that the total contribution of tourism to the EU GDP will be $11.2 \%$, with an average annual growth of $2.2 \%$, higher than other sectors to be found at the centre of public policies, such as the banking and financial sector, manufacturing or transport. Similar to its contribution to economic growth, the tourism industry contributes to the job creation within the European Union with over $10 \%(11.6 \%$ in 2016, with an estimated average annual growth until 2027 of $13.1 \%$ ), exceeding the financial services, banking, automotive manufacturing, chemicals manufacturing, and mining sectors. Tourism is also a leading job generator, with $1 / 5$ of the total number of jobs. It generates 5-6 \% of the total exports and approximately 5\% of total investments (WTTC, 2018). An additional attractiveness of tourism is given by the high resilience capacity of the tourism industry. In general, tourism has high sensitivity to the outbreak of a crisis (economic, political, and military) but it recovers quickly and usually at higher 
growth rates than before the crisis. Therefore, tourism introduces an element of stability to the economic growth of a region, being often viewed as a priority in development policies and an extremely attractive sector for business (Benedek and Lembcke, 2017).

This research seeks to deepen our knowledge of how tourism generates a multiplication effect in the European economy and how and whether it can be capitalized in European policies, on the one hand, to stimulate economic growth and, on the other hand, to reduce development gaps. This paper has been divided into four parts. The first part deals with the review of scientific literature on the subject of tourism multipliers effects, the second part describes the design, research procedures and methods used in the study, as well as the list of indicators, the third part develops the results of the research, and the last part presents the conclusions of the study.

\section{Review of the scientific literature}

A large and growing body of literature has investigated tourism multiplier effect from a theoretical or empirical point of view during the last decades (Ntibanyurwa, 2006; van Leeuwen, Nijkamp and Rietveld, 2009; Pascariu and Tiganasu, 2014). The multiplier effect was mostly used for the determination of economic impact of visitor spending, by multiplying it with the number of tourists and the average spending per visitor (Stynes, 1999). Furthermore, the tourism multiplier effect is seen today as a natural constituent of the tourism activities, some authors including the tourism multiplier effect in tourism definition. According to Goeldner and Ritchie (2003, p.6) tourism could be defined as "the sum of the phenomena and relationships arising from the interaction of tourists, business suppliers, host governments and host communities in the process of attracting and hosting these tourists and other visitors".

Several attempts have been made to delimitate the tourism multiplier effect from other economic sectors multiplier effects. Globally, the largest study was done by the World Travel \& Tourism Council in 2012, when a multiplier effect of 3,2 was found for tourism, higher than for sectors such as communications, financial services, or education (WTTC, 2012). Other specific situations for developing economies are being discussed by case studies conducted across different countries. In a study focused on Ecuadorian economy Croes and Rivera (2017) found that despite a weaker multiplier effect than the agriculture, the tourism could benefit the poor in a more sustainable way. Similar results were found by a study applied to the economy of Panama which found a multiplier twice as big for tourism compared with textile industry (Klytchnikova and Dorosh, 2013). By having strong and sustainable relations with food sector, agriculture, and low industries, hence creating healthy regional synergies, the tourism proves to help the poorer regions (Hjerpe, 2018; Ferrari, Mondéjar Jiménez and Secondi, 2018). Evidence from China suggested tourism is a factor contributing significantly to the reduction of the core-periphery differences ( $\mathrm{Li}$ et al., 2016), although national tourism have a greater impact than the international tourism upon the convergence speed. While tourism is an important sector which promotes economic growth and could help the less developed regions, it should be mentioned that its multiplier effect is largely dependent upon the local and regional tourism policies (Huse, Gustavsen and Almedal, 1998).

A smaller, however consistent par of literature, focused on the tourism multiplier effect upon job creation (Stynes, 1999; Ke, et al., 2011), although the existing research fails to agree on 
the factors influencing job multiplier effect. Overall, the values for tourism multiplier effect on job creation are highly contested and it is even suggested that the data on job creation on tourism sector are inaccurate (Leiper, 1999) because of its ambiguous nature.

The relation between tourism multiplier effect and regional features has been widely investigated. There is a widely accepted relationship between the value of multiplier effect and the level of economic development (Zhang, Madsen and Jensen-Butler, 2007; Yang, Fik and Altschuler, 2018), the more developed regions being able to display higher values of multiplier effects. Additional studies proved that the multiplier effect can be positively influenced by the level of national or regional economic diversification (Muchapondwa and Stage, 2013), due to the chances of involving more sectors of economy, the level of infrastructure (Freeman and Sultan, 1997; Huse, Gustavsen and Almedal, 1998), the number of inhabitants (van Leeuwen, Nijkamp and Rietveld, 2009) or the typology of tourist attractions (for example van Leeuwen, Nijkamp and Rietveld, (2009) found that the coastal destinations where the sun is the main resource tend to have a larger multiplier effect, while the destinations based on cultural resources recorded the lowest values of multiplier effect). Hansen and Jensen (1996) suggested that a richer region dominated by $3+$ stars hotels tends to express a higher multiplier effect than a poorer region dominated by 2 stars' hotels or camping, while Ntibanyurwa (2006) offered evidence for a higher multiplier effect on the regions with small businesses.

Taking into consideration the above-mentioned aspects, our study tries to answer two major questions: 1. What are the macroeconomic indicators which can explain the value of tourism multiplier effect for both GDP and Job Multiplier in EU? 2. Does the tourism multiplier effect follows a core-periphery pattern in EU; and if it does so, can the tourism be used as a factor for reducing regional disparities, as European policies stipulate? The novelty of the study is given by the creation of an explanatory model for tourism multiplier effect for both GDP and Jobs creation. No research has been found that surveyed the tourism multiplier effect on national economies using a similar approach. Furthermore, our study proposes interpretations of results from the perspective of core-periphery differences in the spatial distribution of European tourism and of the potential contribution that tourism can have to reducing disparities in the European economy.

\section{Research methodology}

Our study focused on the European Union countries and used the most recent data available in terms of tourism and economic performance and competitiveness indicators. The main challenge of the study was the difficulty to obtain values for tourism multiplier effect at national level from the national institutes of statistics, since very few countries focus on this particular indicator and no harmonised methodology for its calculation exists at European level.

Thus, an alternative method was used in this research, by using The Travel \& Tourism Competitiveness Index (TCI). TCI is an index calculated by World Economic Forum (WEF, 2017), computed from 14 complementary pillars (TCI_01 - TCI_14), which is measuring the attractiveness of each country to develop tourism business activities within its territory. Although it can be subject for reinterpretations (Croes and Kubickova, 2013; Pulido-Fernández and Rodríguez-Díaz, 2016), TCI has been successfully used in several studies focused on tourism behaviour at international level (Cîrstea, 2014; Seetaram, 
Forsyth and Dwyer, 2016; Rehman Khan, et al., 2017), being an integrated and comprehensive tool for tourism analysis and observation. For the purpose of analysis, we decided to use for the study the 14 pillars which are forming the TCI for a more detailed vision on tourism attractiveness. Additional indicators were introduced, trying to match previous researches on tourism multiplier effect, e.g. Gini coefficient (Lee and Kang, 1998, Alam and Paramati, 2016). The list of indexes and indicators which were used for the study are described in (Annex no. 1). For each indicator, its source, year and acronym used in the study are presented.

While several methods of calculating the tourism multiplier effects exist (Vanhove, 2011), since our research was not centred on the multiplier effect calculation, but rather its explanation, we used the multiplier effect as the rapport between the total and direct contribution of tourism to GDP respectively job creation according to World Travel \& Tourism Council (WTTC) reports. As regards the investigation method, the literature suggests two different approaches: the first one, preferred by a significant part of the literature, is the panel data / time series approach, which offers the advantage of observing a time lag between the independent variables and the emergence of the multiplier effect of tourism (Garin-Mun, 2006; Falk, 2010; Seetanah, 2011; Wu and Wu, 2017; Liu and Song, 2018). Instead, this type of analysis is dependent on the availability of data over a significant period of time in order to allow the identification of time lag.

Equally used is the cross-section analysis (Parrilla, Font and Nadal, 2007; Brida, et al., 2012; Webster and Ivanov, 2014; Santana-Gallego, Ledesma-Rodríguez and PérezRodríguez, 2016), which, although it does not allow time gap observations, is more accurate when is studied the spatial component of the multiplier effect, as well as the spatial interaction between the units. The use of both methods is less common, but occurs when econometric data are combined with sociological or other type of data (Nelson, Dickey and Smith, 2011; Dogru and Bulut, 2018).

For this study we used a cross-section analysis, a decision based on the availability of data on tourism's contribution to GDP, respectively job creation. Our decision was also motivated by the the attention paid to the spatial dimension of the distribution of the multiplier effect. We chose not to use a time-series approach given that multiplier effect for a given country may change over time (Stynes, 1999), thus creating difficulties in isolating the correct indicators. We excluded indicators like tourism origins because it has been previously proved out that the origin of tourist was not related to the consumption pattern (Archer and Fletcher, 1996). Furthermore, it was found that the number of tourists does not influence significantly the tourism multiplier effect (van Leeuwen, Nijkamp and Rietveld, 2009).

Thus, we used Stepwise Regression Analysis for the identification of macroeconomic indicators which can explain the value of tourism multiplier effect. The advantage of this method is that provides an objective screening procedure for independent variables in developing a prediction model. A preliminary test for multicollinearity between the independent variables highlighted a high correlation between the TCI_01BE, TCI_04HRL and TCI_05ICTR indicators. Thus, in order to avoid biases during the Stepwise regression, it was decided to create a composite index, as an average of the three correlated indicators, which was called TCI_145_BR. For the observation of core-periphery pattern it was decided that the best method to adopt for the investigation of a core-periphery pattern was a hierarchical cluster analysis or HCA, an algorithmic approach to find discrete groups with varying degrees of similarity. The advantage of this approach is the ability to investigate the countries at different level of similarity. Data analysis was performed using IBM SPSS Statistics 21, while the cartographic part was realised with ESRI ArcMap 10 software. 


\section{Results and discussion}

The values for the total and direct contribution of tourism to GDP respectively job creation according to WTTC reports are represented in figure no. 1 and figure no. 2. The direct contribution of tourism "reflects the economic activity generated by industries such as hotels, travel agents, airlines and other passenger transportation services [...], the activities of the restaurant and leisure industries directly supported by tourists" (WTTC, 2018). The total contribution of tourism also includes the indirect and induced effects from investment, the supply chain and other induced income impacts, in addition to the direct contributions (WTTC, 2018). In impact studies, it is necessary to take into account all effects (direct, indirect, induced), especially when inter-sectoral comparisons are required in order to adopt the most appropriate development strategies and policies.
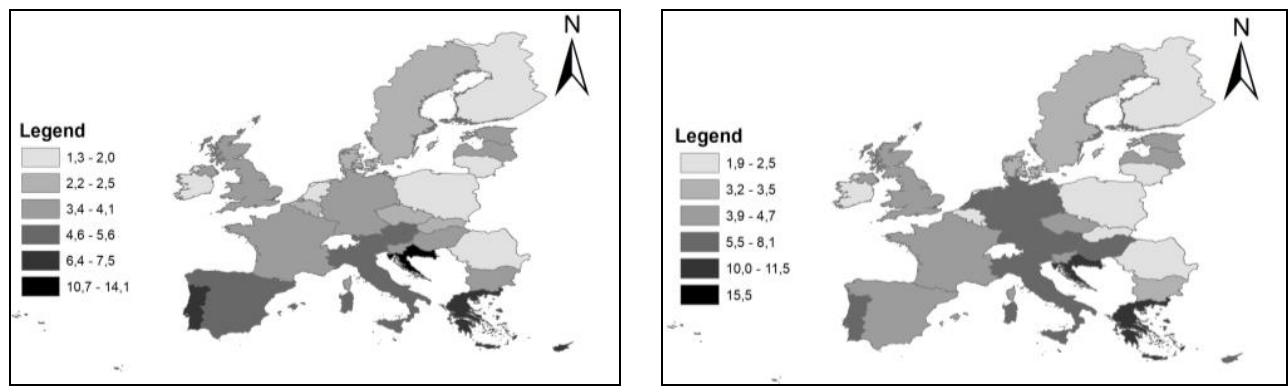

Figure no. 1: Direct contribution of tourism to GDP (left) and job creation in 2016

(right)

Source: Authors' representation based on data from WTTC

The direct contribution of tourism in both GDP and job creation is higher in countries with a tourism tradition, main destinations of the European tourism system, like Portugal, Croatia, Greece, or Italy, moderate in Central Europe in the main European economies, and presents the smallest values in the Eastern periphery. It should be no surprise given that the Eastern Europe have only a few decades of open international tourism and tourism does not benefit from integrated development policies.
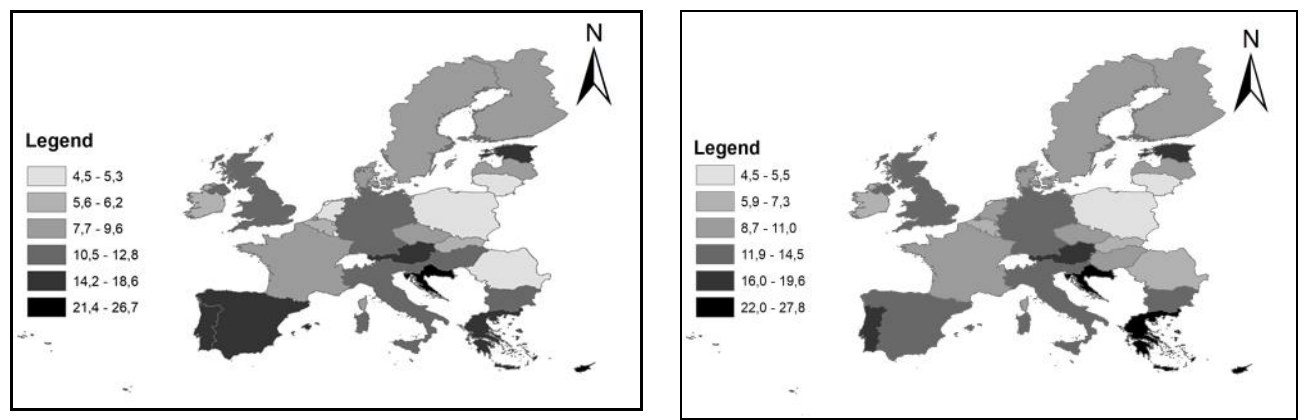

Figura nr. 2: Total contribution of tourism to GDP (left) and job creation in 2016

(right)

Source: Authors' representation based on data from WTTC

Vol. $20 \cdot$ Special No. $12 \cdot$ November 2018 
An interesting observation emerges from the second set of maps showing the total contribution of tourism on both GDP and job creation. It can be observed that several Eastern European countries are improving their places compared with the direct contribution of tourism. These maps suggest a wider multiplier effect in the Eastern European countries, a situation to which the authors have decided to pay extra attention.

In order to investigate this phenomenon, a third set of maps was created: the values of tourism multiplier effect for GDP and jobs creation (figure no. 3). While the tourism multiplier effect tends to present higher values in spatial peripheries from East and North, an inversed spatial core-periphery pattern appears regarding the values of the multiplier, reflecting the potential of tourism to reduce disparities.
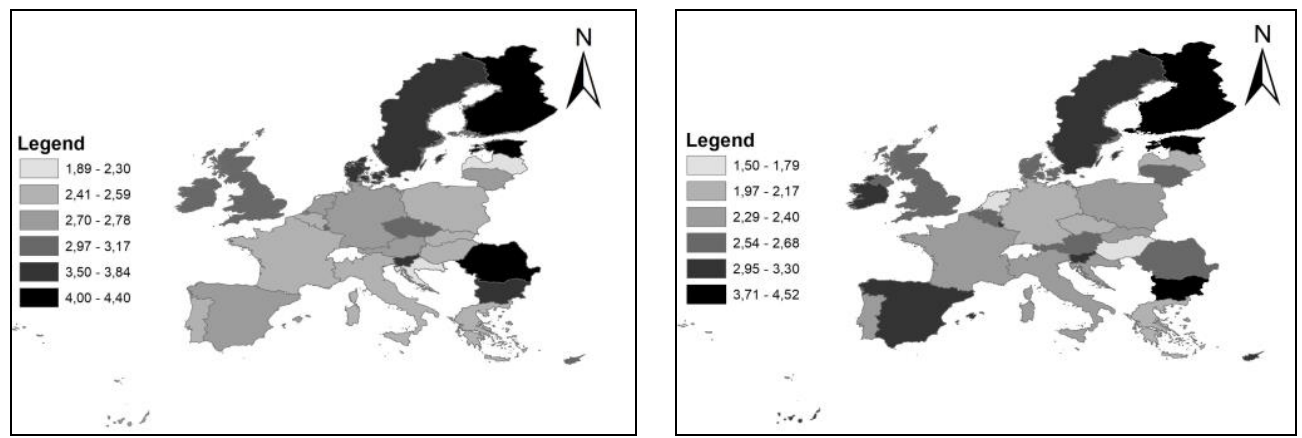

Figura nr. 3: Tourism multiplier effect for GDP (left) and jobs creation (right) in 2016 Source: Authors' representation based on data from WTTC

The tourism multiplier effect used in our research was created by the authors on the basis of the WTTC reports, by reporting the total contribution of tourism to GDP, respectively job creation, to the direct tourism contribution to GDP, respectively job creation. Our hypothesis is that the tourism multiplier effect is helping creating a tourism core-periphery pattern in European Union based on geographical features rather than being the effect of a core-periphery distribution of macroeconomic or tourism competitiveness indicators.

\subsection{Stepwise regression for GDP Tourism Multiplier}

In the first analysis, the GDP tourism multiplier was used as dependent variable. In order to compute a GDP tourism multiplier model, we initially used the following indexes and indicators: AvRA, TCI_02SS, TCI_03HH, TCI_06PTT, TCI_07IO, TCI_08PC, TCI_09ES, TCI_10ATI, TCI_11GPI, TCI_14CRB, TCI_145_BR, GDP_N / C, and Gini coefficient (variables explained in the Annex no.1 and Annex no.2).

As seen in table no. 1, the final model explained $63 \%$ of the variance in GDP tourism multiplier. The best predictors were the TCI_145_BR (Business environment $)^{\dagger}$ followed by TCI_07IO (International Openness), TCI_11GPI (Ground and port infrastructure) and Gini coefficient.

$\dagger$ The full explanation of the composite indicators, as well as the indicators that form them, can be found at the link: http://www3.weforum.org/docs/WEF_TTCR_2017_web_0401.pdf 


\begin{tabular}{|c|c|c|c|c|c|c|c|c|c|c|c|c|}
\hline \multicolumn{13}{|c|}{ Contemporary Approaches and Challenges of Tourism Sustainability } \\
\hline \multicolumn{13}{|c|}{$\begin{array}{l}\text { Table no. 1: Summary of Stepwise Regression Analysis } \\
\text { for Variables Predicting GDP Tourism Multiplier }\end{array}$} \\
\hline \multirow[b]{2}{*}{ Variable } & \multicolumn{3}{|c|}{ Model 1} & \multicolumn{3}{|c|}{ Model 2} & \multicolumn{3}{|c|}{ Model 3} & \multicolumn{3}{|c|}{ Model 4} \\
\hline & $B$ & $\begin{array}{l}S E \\
(B)\end{array}$ & $\beta$ & $B$ & $\begin{array}{l}S E \\
(B)\end{array}$ & $B$ & $B$ & $\begin{array}{l}S E \\
(B)\end{array}$ & $B$ & $B$ & $\begin{array}{l}S E \\
(B)\end{array}$ & $\beta$ \\
\hline Business environment & .42 & .18 & $.42^{*}$ & .67 & .16 & $.67^{* *}$ & .87 & .16 & $.87^{* * *}$ & .89 & .14 & $.89^{* *}$ \\
\hline International Openness & & & & -1.73 & .50 & $-57^{* * *}$ & -1.32 & .46 & $-44^{* *}$ & -1.39 & .41 & $-.46^{* *}$ \\
\hline Ground and port & & & & & & & & & & & & \\
\hline infrastructure & & & & & & & -.34 & .12 & $-.46^{*}$ & -.47 & .12 & $-.65^{* *}$ \\
\hline Gini coefficient & & & & & & & & & & -.05 & .02 & $-.36^{*}$ \\
\hline$\overline{R^{2}}$ & & $.14^{*}$ & & & $.40^{* * *}$ & & & $.53^{* *}$ & & & $.63^{* *}$ & \\
\hline$F$ for change in $R^{2}$ & & $5.55^{*}$ & & & $9.94^{* *}$ & & & $1.05^{* *}$ & & & $12.15^{* *}$ & \\
\hline
\end{tabular}

$* p<.05$. $* * p<.01$.

It is apparent from this table that only the regression coefficient for Business environment (TCI_145_BR) is positive, while the regression coefficients for International Openness (TCI_07IO), Ground and port infrastructure (TCI_11GPI) and Gini coefficient are all negative. The presence of TCI_145_BR in the model is not surprising, since a healthy Business Environment is a sign of facilitated relationships between tourism and other economic sectors. The negative coefficient for Gini can be easily explained by the fact that lower values of Gini coefficient are a sign of more equally wealth distribution, thus enhancing the chances of a high multiplier effect. Previous researches indicated that tourism is more likely to positively affect the multiplier effect by improving earnings and living standards for the lower income class (Lee and Kang, 1998) and Gini coefficient was successfully used for the creation of tourism dispersal metrics (Lau, Koo and Dwyer, 2017). As noted by Alam and Paramati (2016), in developing countries, with high values of Gini coefficient, the multiplier effect will tend to positively affect rather the richer and thus increase the differences between social classes. Given the fact that in the European Union the Gini coefficient present values bellow the global average, thus a sign of a more equally wealth distribution, is no surprise that this variable was included in the model.

The most striking result to emerge from the data is the negative regression coefficient for TCI_07IO (International Openness). Very little was found in the literature on the question of international openness effects towards tourism multiplier effects, however, the regression model does not implies only causality. It should be noted that our analysis does not interpret the effect of International Openness on the increase of tourism demand, effect previously proven as being positive (Chaisumpunsakul and Pholphirul, 2017), it only explains the variance of GDP tourism multiplier. According to our model, the increase in the value of a country's international openness will result in a decrease of the tourism multiplier effect for that country. A second possible explanation is given by the fact that a very open economy will tend to use in a higher degree the imported merchandise to create a more developed tourism chain rather than using its own, and sometimes more expensive products, thus reducing the multiplier effects, while a national centred economy will tend to avoid the leakage effect by providing the needed resources from national sources. However, 
the role of foreign capital proved to be very important (Încalțărău and Maha, 2012), supporting the investments in all sectors, including tourism. Another negative regression coefficient was recorded for TCI_11GPI (Ground and port infrastructure) built around indicators like quality and efficiency of roads, railway and port infrastructure), showing a similar relation like in the case of the international openness. While this may be surprising at first glance, it can be explained by the increase of stationary tourist vacations due to a poorer ground infrastructure. The findings are consistent with those of Leeuwen, Nijkamp and Rietveld (2009) who found that stationary tourist stays have higher multiplier effect and Rehman Khan et al. (2017) who stated that travel and transport services will positively affect outbound tourism rather than inbound tourism in a given country.

\subsection{Stepwise regression for Job Tourism Multiplier}

In the second analysis, the Job tourism multiplier was used as dependent variable. In order to compute a Job tourism multiplier model, we initially used the following indexes and indicators: AvRA, TCI_02SS, TCI_03HH, TCI_06PTT, TCI_07IO, TCI_08PC, TCI_09ES, TCI_10ATI, TCI_11GPI, TCI_14CRB, TCI_145_BR, GDP_N / C, and Gini coefficient (variables explained in the Annex no.1 and Annex no.2).

As seen in table no. 2, the final model explained $44 \%$ of the variance in Job tourism multiplier. The best predictors were the TCI_07IO (International Openness) followed by GDP Nominal per Capita (GDP_N/C). Data from this table can be compared with the data from Table no. 1 which shows a more complex model. In our second analysis, the fewer variables, as well as a smaller percentage are a sign of a weaker model.

Table no. 2: Summary of Stepwise Regression Analysis for Variables Predicting Job Tourism Multiplier

\begin{tabular}{|c|c|c|c|c|c|c|}
\hline \multirow[b]{2}{*}{ Variable } & \multicolumn{3}{|c|}{ Model 1} & \multicolumn{3}{|c|}{ Model 2} \\
\hline & $B$ & $\begin{array}{l}S E \\
(B)\end{array}$ & $\beta$ & $B$ & $\begin{array}{l}S E \\
(B)\end{array}$ & $B$ \\
\hline International Openness & -1.40 & .47 & $-.51^{* *}$ & -2.29 & .49 & $-.84^{* *}$ \\
\hline GDP (nominal) - Per capita & & & & .00 & .00 & $57^{* *}$ \\
\hline$R^{2}$ & & $.23^{*}$ & & & $.44^{*}$ & \\
\hline$F$ for change in $R^{2}$ & & $8.65^{*}$ & & & $10.98^{* *}$ & \\
\hline
\end{tabular}

While the model explains the multiplier effect in a much smaller percentage, it is worth mentioning that the presence of international openness as predictor for both job and GDP multiplier is an indication of the model being partially influenced by the geographical distribution and possibly being highly influenced by the leakage effects. The second predictor, GDP Nominal per capita (GDP_N/C), is supporting the findings of Hansen and Jensen (1996) who found higher multiplier effect in more developed regions with a superior hotel structure.

The models for predicting or calculating the tourism multiplier effects on job creation were a subject of discussion during the last decades, the jobs reported as being directly or indirectly created by tourism activities being usually overestimated by the local authorities. Leiper (1999) estimated that out of 694.000 jobs reported by the Australian authorities as directly created by tourism, only approximatively 200.000 of them were really in tourism. 
Therefore the indirectly created jobs could be wrongly estimated as well and cannot be used in an analysis of impact. A secondary issue in predicting the tourism multiplier effect for job creation is the lack of differentiation in international databases between seasonal and permanent jobs, although previous studies proved that seasonal jobs induce a smaller multiplier effect (Hjerpe and Kim, 2007; Hjerpe, 2018).

\subsection{Hierarchical cluster analysis for core-periphery pattern identification}

The values of GDP and job multiplier effect did not indicate a clear core-periphery patter, however a certain tendency for higher values to group in the Eastern and Northern parts of European Union was observed. Our hypothesis is that the multiplier effect is helping creating a tourism core-periphery pattern in European Union alongside tourism competitiveness and macroeconomics indicators. For our first cluster analysis we used GDP multiplier, job multiplier and TCI.
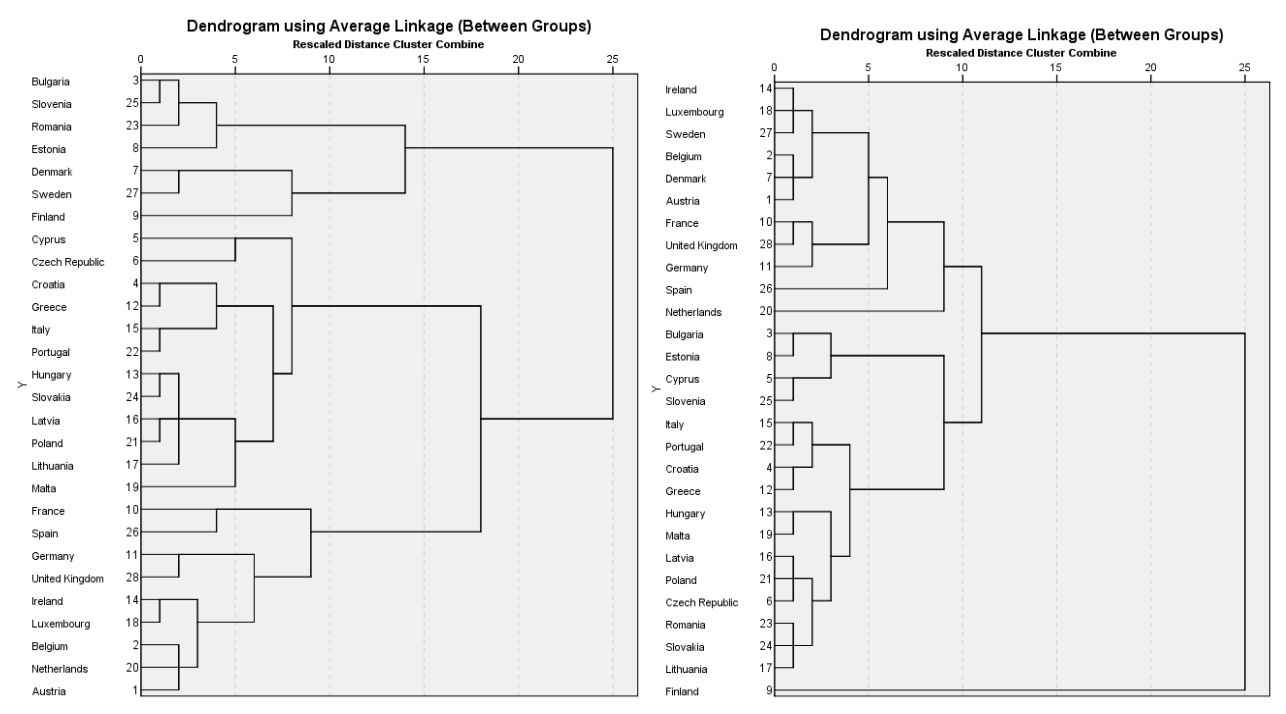

Figure no. 4: Deondograms for Hierarchical cluster analysis 4a GDP tourism multiplier and TCI (left) 4b Job tourism multiplier and TCI (right)

Regarding GDP multiplier, it is apparent from figure no. 4a that the European Union countries are forming three distinct clusters. The first one, the peripheral cluster has two distinct sub-clusters, one with Bulgaria, Slovenia, Romania and surprisingly Estonia, and a northern sub-cluster with Denmark, Sweden and Finland. The second cluster can be defined as a semi-peripheral one, assembling all the countries from 2004 wave, besides Estonia and Slovenia and the southern countries with recent economic issues, Italy Greece and Portugal. Finally, the third cluster, the core cluster is formed by the strong economies from Central and Western Europe.The histogram for job multiplier in figure no. $4 \mathrm{~b}$ indicates a different pattern of clustering. The three clusters Europe is now a rather two clusters Europe, which is almost clearly defining the pre-2004 and post-2004 European Union.

The dendograms indicate a rather spatial core-periphery pattern in GDP and Job tourism multiplier diffusion across European Union, with GDP multiplier presenting a more 
complex structure, in three steps, delineating core, peripheral and semi-peripheral countries, while Job multiplier is describing a rather dual core-periphery pattern. Based on the values of tourism multiplier effect previously obtained and on the explanatory model it is evident that the multiplier effects are reducing the differences between central and peripheral economies in EU. Specifically, for Eastern and Southern countries, where spatial and economic peripheries are correlated, tourism can be used in development policies to reduce the centre-periphery structural differentiations.

\section{Conclusions}

The present study was designed to identify the macroeconomic indicators responsible for higher values of tourism multiplier effect and to put into perspective the potential of tourism in reducing disparities between developed and less developed economies in EU. These findings suggest that the GDP tourism multiplier effect is predicted by Business environment, International Openness, Ground and port infrastructure and Gini coefficient, while Job tourism multiplication effect is predicted by International Openness and GDP (nominal) - Per capita. In the end it has been possible to obtain an explanatory model for both type of multiplier effects with a relevant normative explanatory power.

The evidence from this study supports the idea that tourism multiplier effect is very sensitive to international openness, revenue externalization and wealth distribution across the population. An implication of these results is that all this factors should be taken into account by authorities when developing new tourism strategies. A reasonable approach to tackle this issue could be to develop integrated tourism strategies which will contain not only measures for attractiveness enhancement, but also for value chain support. Reducing socio-economic disparities and providing competitive salaries in tourism sector should be main priorities too, for stakeholders, in order to increase the tourism multiplier effect.

The second major finding was that tourism multiplier effect follows a core-periphery pattern. Hierarchical cluster analysis revealed three clusters for GDP multiplier, respectively two clusters for Job multiplier, each cluster complying with the general spatioeconomic core-periphery pattern of European Union. By presenting higher values in peripheral territories, tourism proves to be an important convergence factor contributing to the sustainable development of the European Union, reducing gaps in economic, social and territorial development. Contrariwise, the high values of multipliers in the Nordic countries, as well as the presence of developed countries in the same clusters as relatively peripheral economies, point to the risk of disparities deepening as a result of tourism development.

These findings have important implications for policy making in EU, supporting the principle of integrating tourism into growth and convergence policies. The results can be used to develop targeted interventions aimed at enhancing multiplier capacity in peripheral regions in order to reduce regional disparities and increase tourism competitiveness. Additionally, increasing the efficiency of the internal market can also boost tourism's contribution to reducing disparities by putting forward key drivers in amplifying multiplier effects. However, more research on this topic needs to be undertaken before the association between tourism multiplier effects and core-periphery model is clearly understood. 


\section{References}

Alam, M.S. and Paramati, S.R., 2016. The impact of tourism on income inequality in developing economies: Does Kuznets curve hypothesis exist?. Annals of Tourism Research, 61(6), pp.111-126.

Archer, B. and Fletcher, J., 1996. The economic impact of tourism in the Seychelles. Annals of Tourism Research, 23(1), pp.32-47.

Benedek, J. and Lembcke, A.C., 2017. Characteristics of recovery and resilience in the Romanian regions. Eastern Journal of European Studies, 8(2), pp.95-126.

Brida, J.G., Bukstein, D., Garrido, N. and Tealde, E., 2012. Cruise passengers' expenditure in the Caribbean port of call of Cartagena de Indias: A cross-section data analysis. Tourism Economics, 18(2), pp.431-447.

Chaisumpunsakul, W. and Pholphirul, P., 2017. Does International trade promote international tourism demand? Evidence from Thailand's trading partners. Kasetsart Journal of Social Sciences, $\operatorname{xxx(2017),~pp.1-8.~}$

Cîrstea, Ş.D., 2014. Travel \& Tourism Competitiveness: A Study of World's Top Economic Competitive Countries. Procedia Economics and Finance, 15(14), pp.1273-1280.

Croes, R. and Kubickova, M., 2013. From potential to ability to compete: Towards a performance-based tourism competitiveness index. Journal of Destination Marketing \& Management, 2(3), pp.146-154.

Croes, R. and Rivera, M.A. 2017. Tourism's potential to benefit the poor: A social accounting matrix model applied to Ecuador. Tourism Economics, 23(1), pp.29-48.

Dogru, T. and Bulut, U., 2018. Is tourism an engine for economic recovery? Theory and empirical evidence. Tourism Management, 67, pp.425-434.

Falk, M., 2010. A dynamic panel data analysis of snow depth and winter tourism. Tourism Management, 31(6), pp.912-924.

Ferrari, G., Mondéjar Jiménez, J. and Secondi, L., 2018. Tourists' Expenditure in Tuscany and its impact on the regional economic system. Journal of Cleaner Production, 171, pp.1437-1446.

Freeman, D. and Sultan, E., 1997. The Economic Impact of Tourism in Israel: A MultiRegional Input - Output Analysis. Tourism Economics, 3(4), pp.341-359.

Garín-Mun, T., 2006. Inbound international tourism to Canary Islands: a dynamic panel data model. Tourism Management, 27(2), pp.281-291.

Goeldner, C.R. and Ritchie, J.R.B., 2003. Tourism: Principles, Practices, Philosophies, London: John Wiley \& Sons.

Hansen, C. and Jensen, S., 1996. The impact of tourism on employment in Denmark: Different definitions, different results. Tourism Economics, 2(4), pp.283-302.

Hjerpe, E.E., 2018. Outdoor Recreation as a Sustainable Export Industry: A Case Study of the Boundary Waters Wilderness. Ecological Economics, 146, pp.60-68.

Hjerpe, E.E. and Kim, Y.-S., 2007. Regional economic impacts of Grand Canyon river runners. Journal of Environmental Management, 85(1), pp.137-149.

Huse, M., Gustavsen, T. and Almedal, S., 1998. Tourism impact comparisons among Norwegian towns. Annals of Tourism Research, 25(3), pp.721-738.

Încalţărău, C. and Maha, L.-G., 2012. The impact of remittances on consumption and investment in Romania. Eastern Journal of European Studies, 3(2), pp.61-86. 
Ke, S.F., Pen, C.G., Pan, J.H., Yan, Z. and Ying, Z., 2011. The multiplier effect of the development of forest park tourism on employment creation in China. Journal of Employment Counseling, 48(3), pp.136-144.

Klytchnikova, I. and Dorosh, P., 2013. Tourism sector in Panama: Regional economic impacts and the potential to benefit the poor. Policy Research Working Papers, The World Bank, [online] Available at: <https://elibrary.worldbank.org /doi/abs/10.1596/1813-9450-6183 > [Accessed 22 January 2018].

Lau, P.-L., Koo, T.T.R. and Dwyer, L., 2017. Metrics to measure the geographic characteristics of tourism markets: An integrated approach based on Gini index decomposition. Tourism Management, 59, pp.171-181.

Lee, C.-K. and Kang, S., 1998. Measuring earnings inequality and median earnings in the tourism industry. Tourism Management, 19(4), pp.341-348.

Leiper, N., 1999. A conceptual analysis of tourism-supported employment which reduces the incidence of exaggerated, misleading statistics about jobs. Tourism Management, 20(5), pp.605-613.

Li, H., Chen, J.L., Li, G. and Goh, C., 2016. Tourism and regional income inequality: evidence from China. Annals of Tourism Research, 58, pp.81-99.

Liu, H. and Song, H., 2018. New Evidence of Dynamic Links between Tourism and Economic Growth Based on Mixed-Frequency Granger Causality Tests. Journal of Travel Research, 57(7), pp.899-907.

Mazilu, S., 2012. A Spatial Perspective over the Creative Economy of the Eastern Europe. Ovidius University Annals, Economic Sciences Series, 12(1), pp.356-360.

Muchapondwa, E. and Stage, J., 2013. The economic impacts of tourism in Botswana, Namibia and South Africa: Is poverty subsiding?. Natural Resources Forum, 37(2), pp.80-89.

Nelson, L.A., Dickey, D.A. and Smith, J.M., 2011. Estimating time series and cross section tourism demand models: Mainland United States to Hawaii data. Tourism Management, 32(1), pp.28-38

Ntibanyurwa, A., 2006. Tourism as a factor of development. In: C.A. Brebbia and F.D. Pineda, eds. 2006. Sustainable Tourism II. Southampton: Wit Press. pp.73-85.

Parrilla, J.C., Font, A.R. and Nadal, J.R., 2007. Tourism and long-term growth - a Spanish perspective. Annals of Tourism Research, 34(3), pp.709-726.

Pascariu, G.C. and Duarte, M.A.P.D.S., 2017. Core-Periphery Patterns Across the European Union: Case Studies and Lessons from Eastern and Southern Europe, Bingley: Emerald Publishing Limited.

Pascariu, G.C. and Tiganasu, R., 2014. Tourism and sustainable regional development in Romania and France: An approach from the perspective of new economic geography. Amfiteatru Economic, 16(8), pp.1089-1109.

Pulido-Fernández, J.I. and Rodríguez-Díaz, B., 2016. Reinterpreting the World Economic Forum's global tourism competitiveness index. Tourism Management Perspectives, 20, pp.131-140.

Rehman Khan, S.A., Qianli, D., Songbo, W., Zaman, K. and Zhang, Y., 2017. Travel and tourism competitiveness index: The impact of air transportation, railways transportation, travel and transport services on international inbound and outbound tourism. Journal of Air Transport Management, 58, pp.125-134. 
Rusu, S., 2011. Tourism Multiplier Effect. Journal of Economics and Business Research, 17(1), pp.70-76.

Santana-Gallego, M., Ledesma-Rodríguez, F.J. and Pérez-Rodríguez, J.V., 2016. International trade and tourism flows: An extension of the gravity model. Economic Modelling, 52(Part B), pp.1026-1033.

Seetanah, B., 2011. Assessing the dynamic economic impact of tourism for island economies. Annals of Tourism Research, 38(1), pp.291-308.

Seetaram, N., Forsyth, P. and Dwyer, L., 2016. Measuring price elasticities of demand for outbound tourism using competitiveness indices. Annals of Tourism Research, 56, pp.65-79.

Stynes, D.J., 1999. Approaches to estimating the economic impacts of tourism; some examples. East Lansing, Mi: Department of Park, Recreation and Tourism Resources, Michigan State University [online] Available at: <https://msu.edu/ course/prr/840/econimpact/pdf/ecimpvol2.pdf > [Accessed 22 January 2018].

UNWTO, 2018. 2017 Annual Report. [online] Available at: <https://www.e-unwto.org /doi/book/10.18111/9789284419807> [Accessed 22 January 2018].

Van Leeuwen, E.S., Nijkamp, P. and Rietveld, P., 2009. A meta-analytic comparison of regional output multipliers at different spatial levels: economic impacts of tourism. In: Á. Matias, P. Nijkamp and M. Sarmento, eds. 2009. Advances in Tourism Economics; New Developments. Heidelberg: Physica-Verlag HD. pp. 13-33.

Vanhove, N., 2011. The Economics Of Tourism Destinations (Second Edition). London: Elsevier.

Webster, C. and Ivanov, S., 2014. Transforming competitiveness into economic benefits: Does tourism stimulate economic growth in more competitive destinations?. Tourism Management, 40, pp.137-140.

WEF, 2017. The Travel and Tourism Competitiveness Report 2017, [online] Available at: <https://www.weforum.org/reports/the-travel-tourism-competitiveness-report-2017> [Accessed 17 November 2017].

WTTC, 2012. The Comparative Economic Impact of Tourism 2012, [online] Available at: $<$ https://www.wttc.org/economic-impact/benchmark-reports/the-comparativeeconomic-impact-of-travel-tourism/> [Accessed 17 November 2017].

WTTC, 2018. Travel \& Tourism Economic Impact 2017, [online] Available at: <https://www.wttc.org/-/media/files/reports/economic-impact-research/regions-2018/ world2018.pdf > [Accessed 17 November 2017].

Wu, T.P. and Wu, H.C., 2017. The Influence of International Tourism Receipts on Economic Development: Evidence from China's 31 Major Regions. Journal of Travel Research, 57(7), pp.871-882.

Yang, Y., Fik, T.J. and Altschuler, B., 2018. Explaining regional economic multipliers of tourism: does cross-regional heterogeneity exist?. Asia Pacific Journal of Tourism Research, 23(1), pp.15-23.

Zhang, J., Madsen, B. and Jensen-Butler, C., 2007. Regional economic impacts of tourism: The case of Denmark. Regional Studies, 41(6), pp.839-854. 
Annex no. 1: Indicators used in the study and data sources

\begin{tabular}{|c|c|c|c|}
\hline Indicator & Year & Source & Acronym \\
\hline $\begin{array}{l}\text { Travel \& Tourism's Direct Contribution } \\
\text { To GDP }(\%)\end{array}$ & 2016 & $\begin{array}{l}\text { World Travel \& Tourism } \\
\text { Council (WTTC) }\end{array}$ & TDC_GDP\% \\
\hline $\begin{array}{l}\text { Travel \& Tourism's Total Contribution To } \\
\text { GDP }(\%)\end{array}$ & 2016 & WTTC & TTC_GDP\% \\
\hline $\begin{array}{l}\text { Travel \& Tourism's Direct Contribution } \\
\text { To Employment }(\%)\end{array}$ & 2016 & WTTC & TDC_E\% \\
\hline $\begin{array}{l}\text { Travel \& Tourism's Total Contribution To } \\
\text { Employment }(\%)\end{array}$ & 2016 & WTTC & TTC_E\% \\
\hline GDP Multiplier Effect 2016 & 2016 & $\begin{array}{l}\text { Author's formula based on } \\
\text { WTTC }\end{array}$ & GDP_M \\
\hline Jobs Multiplier Effect 2016 & 2016 & $\begin{array}{l}\text { Author's formula based on } \\
\text { WTTC }\end{array}$ & Jobs_M \\
\hline Average Receipts Per Arrival - US \$ & 2016 & World Economic Forum & AvRA \\
\hline Travel \& Tourism Competitiveness Index & 2017 & World Economic Forum & TCI \\
\hline 01_Business Environment & 2017 & World Economic Forum & TCI_01BE \\
\hline 02_Safety And Security & 2017 & World Economic Forum & TCI_02SS \\
\hline 03_Health And Hygiene & 2017 & World Economic Forum & TCI_03HH \\
\hline 04_Human Resources And Labour Market & 2017 & World Economic Forum & TCI_04HRL \\
\hline 05_Ict Readiness & 2017 & World Economic Forum & TCI_05ICTR \\
\hline 06_Prioritization Of Travel \& Tourism & 2017 & World Economic Forum & TCI_06PTT \\
\hline 07_International Openness & 2017 & World Economic Forum & TCI_07IO \\
\hline 08_Price Competitiveness & 2017 & World Economic Forum & TCI_08PC \\
\hline 09_Environmental Sustainability & 2017 & World Economic Forum & TCI_09ES \\
\hline 10_Air Transport Infrastructure & 2017 & World Economic Forum & TCI_10ATI \\
\hline 11_Ground And Port Infrastructure & 2017 & World Economic Forum & TCI_11GPI \\
\hline 12_Tourist Service Infrastructure & 2017 & World Economic Forum & TCI_12TSI \\
\hline 13_Natural Resources & 2017 & World Economic Forum & TCI_13NR \\
\hline $\begin{array}{l}\text { 14_Cultural Resources And Business } \\
\text { Travel }\end{array}$ & 2017 & World Economic Forum & TCI_14CRB \\
\hline 145_Business_readiness & 2017 & World Economic Forum & TCI_145_BR \\
\hline GDP (Nominal) - Per Capita & 2016 & $\mathrm{IMF}$ & GDP_N/C \\
\hline Gini coefficient & 2015 & Eurostat Data Explorer & Gini \\
\hline
\end{tabular}


Annex no. 2: Indicators: Descriptive Statistics

\begin{tabular}{|c|c|c|c|c|c|}
\hline Indicator & $\mathbf{N}$ & Minimum & Maximum & Mean & $\begin{array}{c}\text { Std. } \\
\text { Deviation }\end{array}$ \\
\hline TDC_GDP\% & 28 & 1.30 & 14.10 & 4.13 & 2.91 \\
\hline TTC_GDP\% & 28 & 4.50 & 26.70 & 11.33 & 6.04 \\
\hline TDC_E\% & 28 & 1.90 & 15.50 & 5.04 & 3.19 \\
\hline TTC_E\% & 28 & 4.50 & 27.80 & 12.32 & 6.19 \\
\hline GDP_M & 28 & 1.89 & 4.40 & 2.96 & 0.62 \\
\hline Jobs_M & 28 & 1.51 & 4.52 & 2.63 & 0.67 \\
\hline AvRA & 28 & 346.70 & 3943.30 & 872.44 & 665.73 \\
\hline TCI & 28 & 3.78 & 5.43 & 4.47 & 0.46 \\
\hline TCI_01BE & 28 & 3.90 & 5.90 & 4.80 & 0.58 \\
\hline TCI_02SS & 28 & 5.10 & 6.70 & 5.90 & 0.37 \\
\hline TCI_03HH & 28 & 5.70 & 6.90 & 6.34 & 0.31 \\
\hline TCI_04HRL & 28 & 4.40 & 5.70 & 5.08 & 0.38 \\
\hline TCI_05ICTR & 28 & 4.70 & 6.40 & 5.55 & 0.50 \\
\hline TCI_06PTT & 28 & 3.80 & 6.20 & 4.84 & 0.60 \\
\hline TCI_07IO & 28 & 3.70 & 4.50 & 4.09 & 0.20 \\
\hline TCI_08PC & 28 & 2.80 & 5.50 & 4.49 & 0.58 \\
\hline TCI_09ES & 28 & 4.00 & 5.60 & 4.80 & 0.40 \\
\hline TCI_10ATI & 28 & 1.70 & 5.20 & 3.62 & 0.96 \\
\hline TCI_11GPI & 28 & 2.80 & 6.10 & 4.64 & 0.80 \\
\hline TCI_12TSI & 28 & 4.20 & 6.70 & 5.40 & 0.75 \\
\hline TCI_13NR & 28 & 2.20 & 4.90 & 3.36 & 0.87 \\
\hline TCI_14CRB & 28 & 1.40 & 6.80 & 3.12 & 1.75 \\
\hline TCI_145_BR & 28 & 4.47 & 5.87 & 5.14 & 0.46 \\
\hline GDP_N/C & 28 & 7369.00 & 101715.00 & 31100.18 & 20765.22 \\
\hline Gini & 28 & 25.00 & 37.90 & 30.36 & 3.88 \\
\hline
\end{tabular}

